\title{
English as a Medium of Instruction: Students' Discernment in Nepal
}

\author{
- Nani Babu Ghimire \\ Lecturer, Siddhajyoti Education Campus
}

\begin{abstract}
English as a medium of instruction (EMI) has become a global phenomenon; and several countries of the world have adopted EMI in their classrooms from primary to university level including Nepal. This study seeks to explore the perception, practice and challenges of the students allied to using EMI for learning at secondary level in the community schools of Nepal. It looks at students' attitude on EMI in terms of their upbeat mind-set, complicatedness and identity construction. A critical qualitative case study method was adopted for research and three students of an EMI-adopted community school of Sindhuli district were selected as the participants of study following the purposive sampling procedure. Semi-structured interview was conducted to elicit in-depth data from the participants. The raw data were transcribed and coded to develop the main themes maintaining the principles of relevancy. The findings reveal that the students have deeply rooted beliefs in learning through English because it secures their future by assisting them to get a job in the country or abroad. They have difficulties in speaking English and learning new vocabulary even though they are learning through English; but their teachers facilitate them with the Nepali equivalents. They feel proud of being the students of EMI schools because there is a superior credit of their school in the district and they are also supposed to be better qualified students in their locality.
\end{abstract}

Keywords/terms: EMI, upbeat mind-set, complicatedness, identity construction

\section{Introduction}

As an international language, English is widely used in business, trade, tourism, media, court, parliament, diplomacy, informational technology, and as an official language all over the world. In this sense, Byun and others (2011, p. 43) have remarked: 
Given today's degree of globalization and the dominance of English as a global lingua franca, a working knowledge of spoken and written English is increasingly perceived as an indispensable competency in various fields including business, diplomacy, andmore and more-academia.

English is regarded as a prestigious language because of its power in the present era. It is believed that one who is capable in English can survive at home or abroad easily. Sah (2015, p. 1) has asserted, "The rise of English as a global lingua franca seems to be further forcing non-native speakers to learn English and many countries are trying to drastically overhaul their education system in favour of English in order to meet the challenge of global integration". In the recent context of Nepal, people are attracted towards English medium of education because English is a global language and their children can get immense opportunities if they develop competence in English. In this regard, Sah and Li (2018, p. 109) have stressed, "There is an increasing (uncritical) trend among non-English-speaking countries to adopt English medium of instruction (EMI) policy in schools for the last couple of decades". In English medium schools the non-language subjects such as science, social studies, health and population, culture, history etc. are taught through English. Addressing the magnetism of people towards English in the world, Dearden (2014, p. 4) has added:

EMI is increasingly being used in universities, secondary schools and even primary schools. This phenomenon has very important implications for the education of young people. Yet little empirical research has been conducted into why and when EMI is being introduced and how it is delivered.

Institutional schools began to provide education in English medium in the urban areas of Nepal. Discussing this issue, Ojha (2018, p. 190) mentions:

After the restoration of democracy in Nepal in 1990, governments adopted a liberal policy to allow the establishment of private schools. These schools were opened in district headquarters and other cities, used English as the exclusive medium of instruction and made the language accessible to people who could afford to pay the tuition fees.

The result of these schools was considered satisfactory in the parents' perception, and they sent their children to EMI school - i.e. institutional schools. The number of students increased in institutional schools, and such 
schools spread also to the rural and remote areas. Rural people considered the English medium schools (institutional schools) to be better than others, and they sent their children to these schools in the name of quality education. Such fashion of the institutional schools caused the problem to community schools by attracting more students to them and decreasing the number of students in community schools. Then, the community schools have also been shifting into EMI schools both in rural and urban areas.

The government does not have any policy for EMI, but schools are providing education through English medium; and parents are sending their children blindly to such schools. In terms of policy, Phyak (2011, as cited in Ranabhat and others, 2018, p. 84).) commented: "The MOE [Ministry of Education] does not have any policy regarding the English medium of instruction in schools (although there is a tide of English in schools)". This type of policy made by school itself obstructs the cognitive development of students because they cannot take part in the learning activities actively because of lack of competence in language. As regards policy, Karki (2018, p. 204) stated, "it is perhaps even more surprising that the government of Nepal does not have basic statistics related to EMI, not even the number of schools practicing EMI. Schools can even adopt or withdraw from EMI whenever they wish".

The studies done in Nepal have shown that there are many problems in institutional as well as community schools where EMI is used in terms of classroom management, provision of qualified and trained teaches, English learning environment, availability of teaching learning materials, language ideology, identity construction of teachers and students. Therefore, reflecting on my own experiences in teaching field and observing the practice of learning academic subjects through English in community schools in Nepal, I have decided to explore the attitude and awareness of students concerning their practical experience in EMI-based community schools selected for this study.

\section{Purpose and research questions}

The main purpose of this study was to explore the perception, practices and challenges of the students associated with using EMI in selected community schools of Nepal. The study attempts to answer the following research questions in particular.

- How do the students perceive and practice EMI in community schools?

- What problems do they face regarding EMI? Does it help them to express their ideas? 
- What language ideology and identity do they have as the students of EMI schools?

\section{Literature review}

English is increasingly recognized as an indispensable requirement in various fields including business, diplomacy and academics. The role and scope of English has grown immensely during the past few decades due to globalization and the concomitant increase in personal mobility and intercultural exchanges (Byun and others, 2011, p. 432). It facilitates global exchange of information, development of knowledge, and prospects for career advancement and mobility (Montgomery, 2004). Regarding English as a global phenomenon, institutional and some community schools of Nepal (a country which is multi-lingual in character) have adopted EMI for classroom instruction, like other countries of the world where English is used as either a foreign language or a second language.

Cosgun and Hasirci (2017, p. 12) have defined, "EMI means delivering course content by using the English language with the assumption that all the lessons, assignments and course materials used in the course are all in English". In this setting, faculty members' primary concern is not to improve students' language ability while delivering the content in English. Similarly, Ibrahim and others (2017, p. 64) have stressed:

In any teaching and learning situation the language of instruction plays a very vital role in facilitating learning of subject contents. So it is necessary for the teachers and learners to use the language of instruction appropriately for enhancing effective teaching and learning.

Crystal (2004) avowed that adoption of EMI has been sweeping across the higher education landscape worldwide. Likewise, Nunan (2003) also supported that EMI has also emerged in Asian countries. Hu (2009, p. 47) concluded:

Although the organised promotion of EMI in contemporary China started only at the turn of this century, the use of EMI in China's educational institutions has gathered great momentum in the last few years and is now sweeping across the educational landscape.

Considering EMI in Nepal, Phyak, (2011b) observed that these days, rather than implementing multilingual education, an increasing number of community schools are shifting from Nepali to EMI to compete with 
institutional schools and to justify the view that community schools are not different from institutional schools in terms of quality. It is a common perception among Nepalese people that children will have better future prospects if they have English medium schooling (Aryal, 2013). In Nepal, the achievement gap between students from institutional and community schools has produced an ideological impression in parents that Englishmedium schooling provides quality education. Thus, Nepalese community schools are moving from Nepali to English medium. With reference to these issues in the context of Nepal, Ojha (2018, p. 196) stressed:

Introducing EMI is not a solution to overcoming the long-standing problem of degradation of quality education in community schools $[\ldots]$ it is suggested that community schools should focus on teaching effectively in their students' mother tongue rather than teaching in English and the medium should not be changed solely as a survival technique to compete with institutional schools.

Doiz and others (2012, as cited in Sah and $\mathrm{Li}, 2018$, p. 112) put forward that although many Asian countries, including Nepal, are opting into EMI for human capital development, this goal may be hard to achieve due to the lack of preparedness for EMI policy and inadequate English skills of both teachers and students.

\section{Methodology}

The study builds on the critical qualitative case study research design. Case studies can employ an embedded design, that is, multiple levels of analysis within a single study (Yin, 1984). According to Eisenhardt (1989, p. 534), "Case study is a research strategy which focuses on understanding the dynamics present within single settings". He further adjoined, "Case studies typically combine data collection methods such as archives, interviews, questionnaires, and observations". I chose Shree Devisthan Secondary School Dumja (DSSD), Sunakoshi Rural Municipality-1, Sindhuli, Nepal as a research site which has been implementing the EMI policy over the past 16 years. In this context, Skutnabb-Kangas (1981, as cited in Agai-Lochi, 2015, p. 341) points out, 'values', 'norms' and 'ideology' established by the school is a law that is accepted by all including linguistic minorities. DSSD, situated in a rural area of Sindhuli district, is a partially government aided community school with about 400 students. The founder president of the school management committee (SMC) said, "This school has not got full quota of teachers from the government for the secondary level. The school itself has managed the required 
teachers by collecting a little tuition fee from the parents. The result of the school is praised by everyone surrounding the school. This school is one of the best schools of the district regarding the result in the Secondary Education Examination (SEE)". The school is located in the community in which people belonging to diverse cultural and linguistic backgrounds reside - including Tamang, Magar, Newar, Majhi, Brahman, Kshetri, Dalit (Dmai, Kami, Sarki).

DSSD had changed the medium of instruction (MOI) from Nepali to English in 2003 from class Nursery to One and, then it was upgraded step by step upto class Two to Ten. The head teacher said that both teachers and students struggled hard in implementing EMI. The result of the SLC examination in 2012, in which the first group of EMI-based students were involved, proved their school as one of the best schools in the district obtaining good results. The head teacher also informed that all parents, SMC members, teachers, and students collaborate for the progress of the school.

I selected 3 students of DSSD as the participants of the study. Among them, 2 were from Grade Nine, 1 from Grade Ten; 1 was male and 2 were female; 1 was from Brahman community, and 2 were from other ethnic groups. To ensure secrecy, each participant was given a pseudo name during the interpretation of the data as, Anita, Shanta, and Raman. They had studied in DSSD from Grade 3, 8 and 1 respectively.

The school and the participants were selected following a purposive sampling technique. A semi-structured interview was used to elicit the indepth data from the informants. All interviews were audio-recorded; the raw data were transcribed, and then the main themes were generated through content analysis. The ideas of the participants were interpreted under those themes linking them to the literature reviewed in this study.

\section{Results and Discussion}

The findings of the study have been discussed under three major thematic areas: Upbeat mind-set towards EMI, complicatedness in EMI, and identity construction of students in EMI.

\section{Upbeat mind-set towards EMI}

The belief about English is increasing in Nepal as well as in the world. Considering language ideology, Ghimire (2011, p. 2) expressed, "it represents the beliefs of people towards particular languages or language varieties and the value they assume for each of them". Students perceive EMI policy of community schools positively in Nepal. They think that they 
have got a great opportunity to study in an EMI-based school in this globalized world. Supporting this view, Kruseman (2003, as cited in Cosgun and Hasirci, 2017, p. 12) have suggested that the medium of education should be English so that students can be equipped for an international career in today's globalizing world. In this regard Anita, a participant, said:

I come to study in this school walking 3 hours because the MOI is English. I prefer EMI since we get quality education through it. We can go abroad for our further study, and we will get a good job if our English is good. My native language Tamang is used only in my home environment but English is used globally.

This remark reveals that the students are keenly interested in learning through English, with the belief that learning through English enables them to acquire quality education. Regarding this issue, Sharma (2016), claimed that parents equated English medium education with quality education which, according to him, is the 'English as a quality' myth. Gazing at this idea of students, Khati (2016, p. 25) argued that more strikingly, teachers take for granted that teaching in English helps students find a job and participate in the global community. In the same vein, Thapa $(2016$, p. 97) stated that the reason for adopting EMI is to make the graduates get job opportunities within the country and abroad. Explaining the reasons for studying in EMI schools, Shanta, another participant, added, "I am studying in this school living in my maternal uncle's house because the teachers teach us in English and our textbooks are also in English. If we are able in English, we can easily survive in the future".

These accounts make it clear that the people who are living in rural areas also have a strong desire to make their children capable in English. As Dearden (2014, p. 21) found, "EMI is highly supported by the parents". Observing this kind of attitude in parents, Milligan and Tikly (2016, p. 277) noted:

Almost all low- and middle-income, postcolonial countries now use English or another 'global language' as the medium of instruction at the secondary and tertiary level. An increasing number use English language as a medium of instruction in the latter stages of primary schooling and at pre-school levels although it is not the mother tongue for the majority of learners.

Considering the opinion of Shanta about the use of the English textbook and learning English, Ojha (2018, p. 190) examined that students use textbooks 
written in English, they read and write answers in English, and the written examinations are conducted in English. Likewise, Raman (in this study) said:

I have been studying in this school since the beginning of my school life. My parents are farmers. They admitted me in this school because they cannot afford expensive tuition fee at an institutional school. We can study through English at nominal fee rate here. We can easily compete with the students of institutional schools.

After scrutinizing this thought, I can claim that the community school is now shifted into EMI because of the institutional schools, which were established rapidly in the country when the Government followed the neoliberal policy in education. The institutional schools were expensive but they became famous at the parents' glance; and they created pressure to the community school shift their medium of instruction from Nepali to English, for managing quality education at a nominal fee.

Giri (2011) observed that the gap in achievement between the students from institutional schools and community (public) schools has produced an ideological impression in parents that English-medium schooling provides quality education. Considering this fact, Phyak (2013) stated that as institutional schools are virtually English medium, they have shaped the parents' beliefs about the value of different languages in the community. The institutional schools in the village have already entrenched the assumptions like 'English-as-a-language-for-prosperity' and 'English-medium-as-quality education' among parents.

\section{Complicatedness in EMI}

The narration of the students made me clear that they are satisfied in their study in EMI school; but they have problems as well. Talking about the difficulties in learning in EMI, Anita articulated: "In the beginning I could not understand anything in English as my first language is Tamang. I experienced convolution in learning the meanings of words but now-a-days the teachers address my problems by using Nepali equivalents".

From this description I found that she is from a backward ethnic group; and she feels difficulty in learning new vocabulary items, then her teachers translate them into Nepali. It means it is not absolute EMI, but a translingual process employed in language learning. Considering a similar matter in a study in Nigeria, Ibrahim and others (2017, p. 66) have stated, "Pupils use different languages such as Hausa and English as well as code mixing and 
code switching during lessons in their classrooms". Such use of learners' native language is useful for learning English as well. Trudell (2016, as cited in Brown, 2018, p. 22) has summarized the same as, "The research indicates that using the learners' mother tongue in the classroom enhances classroom participation, decreases attrition, and increases the likelihood of family and community engagement in child's learning". Correspondingly, elucidating the complexity of student learning in EMI, Shanta, a participant, expressed:

When I came here to study from a Nepali medium school, I experienced intricacy in learning through English. In course of classroom teaching, if we did not understand any contents, we asked in Nepali and our teachers answered in English as well as in Nepali. I could write in English but had difficulty in speaking.

The clarification made by Shanta indicates that in the beginning she faced difficulties in learning through English. In a similar circumstance, Milligan and Tikly (2016, p. 280) obviously affirmed that there is the importance of the inclusion of learners' first language in EMI classrooms particularly in the transitional years. Shanta's statement proclaims that she was weak in speaking. Khati (2016, p. 29) mentioned: "Most importantly, researchers have critiques on the weak pedagogical aspect of EMI in multilingual situation, particularly on the process of communication inside the classroom". To improve the situation, the teachers as well as students should engage in interaction or communication practice in English. Taking part in conversation, Raman insisted on the following:

I have been studying in the English medium from the beginning. I can speak English either inside the classroom or outside. I do not always speak English in school premises because my friends might feel humiliated if they cannot speak English with me.

Brown (2018, p. 22) opined that MOI not understood by the learner impedes learning and holds them back in cognitive development. He wants to learn everything in English but his friends do not understand English to talk with him. Sah and Li (2018, p. 120) supported Raman's view, and stated that EMI within the framework of Nepali instruction did not seem to aid either content learning or English language acquisition. These opinions explain Raman's remark.

\section{Students' identity construction in EMI}

Identity normally indicates a specific characterization of someone. Wenger (1998, as cited in Khati, 2018, p. 242) views identity as showing the social, 
cultural and historical aspects of a person. Personal emotions, belief, knowledge and attitude are important in shaping student identity (Phyak, 2011a). Regarding her identity as a student of an EMI school, Anita said:

I am a girl from Tamang community. I can write in English and can read English texts fluently. I can also understand English and can speak with my friends in English. This all happened because of EMI. Every year in SEE, our school obtains the best result and everyone praises the result of our school. So I feel proud of being a student of this EMI school.

A girl belonging to Tamang ethnic group, Anita is so conceited that she frankly identifies herself as a student of an EMI school. But, in this regard, Yasui and others (2004) found ethnic identity to be a significant predictor of student achievement for a group of African-American students. On the other hand, Cokley and Chapman (2008) suggested that the importance of fostering a positive student identity lies in fostering a positive academic selfconcept and its negative link to devaluing academic success, both of which are strongly predictive of academic achievement. Reflecting her inspiration as a student of an EMI school, Shanta explained, "I came here from very far to study through English. I learned to write and speak through English. [Now] I can read English texts easily. By observing my progress in English, my parents are very satisfied".

The comment made by Shanta exposed that she is proud of her progress through EMI, as her parents and neighbours are praising her improvement. Ropo (2013) supported this kind of exploration and said that identity is an important concept in understanding action and behavior which helps in the meaning making process in and outside school learning, and it relates on what kind of meanings we create from the received information and about ourselves as learners. However, Raman put his inspection as:

I do not feel so much proud of learning through the English language. All languages are equal. I am proud as the student of my school since the result of my school is the best in the district; and this has happened because of the good management and cooperation among SMC, students and teachers, not only due to EMI.

The reflection made by Raman indicates that studying through EMI is not a way of creating student identity, but the quality education provided by the school with a special attention to its proper management assists them to construct their new identity. Regarding the different aspects of school 
management as mentioned by Raman, Hallinan (2008) found that teacher support for students has positive effects on their increased liking of school. Likewise, Cornelius-White (2010) demonstrated moderate correlation between positive teacher-student relations defined in various ways, including several resembling caring, and multiple measures of student cognitive and affective outcomes, such as self-esteem and identity.

\section{Conclusion and implications}

EMI is unquestionably a growing phenomenon in Nepalese public education. It is thought to open the door to the possibilities for lofty academic and economic offers at local and international levels (Khati, 2016, p. 29). Given the dominance of English as a lingua franca, the expansion of EMI at Nepalese schools is an inevitable process that is likely to continue well into the future. This study examined how EMI is followed in community schools of Nepal, how the students perceive EMI, what challenges they face and what identity they construct through it. As explored in data analysis, students have strong ideologies favouring EMI as, they think, it helps them to expand their knowledge and skill in English providing quality education ensuring a good job and opportunity in the future. Likewise, they believe that EMI facilitates them to create access to higher education and economic development in the global market. Conversely, the students have dealt with challenges such as difficulty in understanding new vocabulary, speaking in English with other friends, getting meaning from the textbooks, etc. It happens because of switching a school from the Nepali medium to English medium without an adequate plan and preparation. In this regard, Sah and $\mathrm{Li}$ (2018) concluded that EMI within the framework of Nepali instruction did not seem to aid either content learning or English acquisition. The content teachers heavily relied on code-mixing and translation, using this approach ineffectively, as they were not trained enough to conduct their job well. In this sense, EMI without 'real' English education gave the poor and workingclass children the illusion of access. Students have constructed their identity as they feel proud of being the students of a well-managed and recognized school with quality education.

Students and their parents are motivated towards EMI; but there is some lacking as the teachers use the Nepali language to deliver the lesson; and the students use Nepali in school premises. The school has its own name and fame in the district not only because of EMI but also of its proper and effective management in the collaborative participation of teachers, students, parents and SMC members. In this case, Bukhari and Awan (2018, p. 803) 
have emphasized that management needs to initiate the teacher training programs so that they become able to implement the role of EMI properly. It should be the responsibility of teachers to utilize the EMI techniques in the classroom. Likewise, the syllabus, textbooks and teaching learning materials need to be designed to address the difficulty of students that could be helpful for them to comprehend the content effectively.

This study is based on the data collected from a small number of participants. Further research can be conducted in the area of EMI with special focus on policies, practices, gaps and implementation strategies in the context of Nepal in particular.

\section{References}

Agai-Lochi, Emrije. (2015). English as medium of instruction in university education. Social and Behavioral Sciences, 199, pp. 340 - 347. Doi: 10.1016/j.sbspro.2015.07.557

Aryal, Mallika. (2013). Nepal scores low on quality education. Global Issue. [blog] 09 July. Available at: http://www.globalissues.org/news/2013/ 07/09/17013 [Accessed 22 December 2018].

Brown, Rhona. (2018). English and its roles in education: Subject or medium of instruction? In Hayes, David (Eds), English Language Teaching in Nepal: Research, Reflection and Practice, pp. 187-200. Kathmandu: British Council.

Bukhari, Syeda Samrah; and Awan, Abdul Ghafoor. (2018). English as a medium of instruction: Investigating the perceptions of secondary school students. Global Journal of Management, Social Sciences and Humanities, 4(4), pp. 785-806. Retrieved from:file:///C:/Users/Dell/ Downloads/SamrahBukhari\%20(1).pdf.

Byun, Kiyong; Chu, Huijung; Kim, Minjung; Park, Innwoo; Kim, Suhong; and Jung, Juyoung. (2011). English-medium teaching in Korean higher education: Policy debates and reality. High Education 62, pp. 431-449. Doi:10.1007/s10734-010-9397-4.

Cokley, Kevin; and Chapman, Collette. (2008). The roles of ethnic identity, anti-white attitudes, and academic self-concept in African American student achievement. Social Psychology of Education. Doi: 10.1007/ s11218-008-9060-4.

Cornelius-White, Jeffrey. (2010). Learner-centered teacher-student relations 
are effective: A meta-analysis. Review of Educational Research, 77, pp. 113-143. Retrieved from: https://www.researchgate.net/publication/ 240723606.

Cosgun, Gulcin; and Hasirci, Bahar. (2017). The impact of English medium instruction (EMI) on students' language abilities. International Journal of Curriculum and Instruction, 9(2), pp. 11-20. Retrieved from: http://ijci. wcci-international.org/index.php/IJCI/article/view/73.

Crystal, David. (2004). The past, present, and future of World English. Globalization and the future of German (Berlin: Mouton de Gruyter), 2746. Retrieved from: January 28, 2019, http://ww.davidcrystal.com/DC_ articles/English9.pdf.

Dearden, Julie. (2014). English as a medium of instruction- a growing global phenomenon. British Council. Retrieved from:https://www.britishcouncil. org/sites/default/files/e484_emi_cover_option_3_final_web.

Eisenhardt, Kathleen. (1989). Building theories from case study research. Academy of Management Review, 14(4), pp. 532-550. Retrieved from: https://pdfs.semanticscholar.org/ad19/b994ed568156c5e9ca8763e8013bc 5d1e0c6.pdf.

Ghimire, Laxman. (2011). Ideologies in the educational language policies of Nepal. Nepalese Linguistics, 26, pp. 36-44. Retrieved from: https://www. academia.edu/1788854/Ideologies_in_the_educational_language_policies _of_Nepal.

Giri, Ram Ashish. (2011). Languages and language politics: How invisible language politics produces visible results in Nepal. Language Problems and Language Planning, 35(3), pp. 197-221. Doi:10.1075/lplp.35.3.

Hallinan, Maureen. (2008). Teacher influences on students' attachment to school. Sociology of Education, 81, pp. 271-283. Retrieved from: https:// www.researchgate.net/publication/249802963.

Hu, Guangwei. (2009). The craze for English-medium education in China: Driving forces and looming consequences. English Today, 25(4), pp. 4754. Doi:10.1017/S0266078409990472.

Ibrahim, Hadiza AlHassan; Anka, Shafaatu Muhammad; and Yabo, Nafisat Umar. (2017). English as a medium of instruction: Challenges to Nigerian primary schools. Journal of Simon Fraser University Library, 5 (2), pp. 63-72. Retrieved from: https://journals.sfu.ca/vict/index.php/vict/ 
article/viewFile/247/124.

Karki, Jeevan. (2018). Is English medium instruction working? A case study of Nepalese community schools in Mt. Everest region. In Hayes, David (Ed.), English language teaching in Nepal: Research, reflection and practice, pp. 202-216. Kathmandu: British Council.

Khati, Ashok Raj. (2018). Socio-cultural characteristics of English teachers in a Nepali hinterland: A case study. In Hayes, David. (Ed.), English language teaching in Nepal: Research, reflection and practice, pp. 187200. Kathmandu: British Council.

Khati, Ashok Raj. (2016). English as a medium of instruction: My experience from a Nepali Hinterland. Journal of NELTA, 21(1-2), pp. 23-30.

Milligan, Lizzi; and Tikly, Leon. (2016). English as a medium of instruction in postcolonial contexts: Moving the debate forward. Comparative Education, 52(3), pp. 277-280. Doi: 10.1080/03050068.2016.1185251.

Montgomery, Scott. (2004). Of towers, walls, and fields: Perspectives on language in science. Science, 303(5662), pp. 1333-1335. Retrieved from: https://www.ncbi.nlm.nih.gov/pubmed/14988554.

Nunan, David. (2003). The impact of English as a global language on educational politicies and practices in the Asia-pacific region. TESOL Quarterly, 37(4), pp. 589-613. Retrieved from: http://www.nzdl.org/gsdl/ collect/literatu/index/assoc/HASH01fc.dir/doc.pdf.

Ojha, Laxmi Prasad. (2018). Shifting the medium of instruction to English in community schools: Policies, practices and challenges in Nepal. In Hayes, David (Ed.), English Language Teaching in Nepal: Research, Reflection and Practice, pp. 187-200. Kathmandu: British Council.

Phyak, Prem Bahadur. (2011a). Construction of teacher identity: individual or social. English Language Teaching Vision Pokhara, 2, pp. 47-60.

Phyak, Prem Bahadur. (2011b). Beyond the facade of language planning for Nepalese primary education: Monolingual hangover, elitism and displacement of local languages? Current Issues in Language Planning, 12(2), pp. 265-287.

Phyak, Prem Bahadur. (2013). Language ideologies and local languages as the medium of- instruction policy: a critical ethnography of a multilingual school in Nepal. Current Issues in Language Planning, Doi:10.1080/ 14664208.2013.775557. 
Ranabhat, Min Bahadur; Chiluwal, Subodh Babu; and Thompson, Richard. (2018). The spread of English as a medium of instruction in Nepal's community schools. In Hayes, David (Ed.), English language teaching in Nepal: Research, reflection and practice (81-106). Kathmandu: British Council.

Ropo, Eero. (2013). Identity, school and student learning. Retrieved from: https://www.windesheim.nl/ /media/files/windesheim/onderzoek/onderz oek/onderzoeksthemas/educatie/726keynoteropokeynote22052013e.pdf?1 $\mathrm{a}=$ nl-nl.

Sah, Pramod Kumar; and Li, Guofang. (2018). English medium instruction (EMI) as linguistic capital in Nepal: Promises and realities. International Multilingual Research Journal, 12(2), pp. 109-123. Doi: 10.1080/ 19313152.2017.1401448.

Sah, Pramod Kumar. (2015). English medium instruction (EMI) in Nepalese education: potential or problem? [Blog article]. ELT CHOUTARI. Retrieved from: <http://eltchoutari.com/2015/08/english-mediuminstruction -emi-in-nepalese-educationpotential-or-problem/>.

Sharma, Shyam. (2016). Myths about English in Nepal. Available online at: http:// shyamsharma.net/myths-about-english-in-nepal.

Shrestha, Prithvi. (2008). ELT, ESP and EAP in Nepal: Whose interests are served? In: Krzanowski, Mark (Eds.). EAP and ESP in developing countries: State of play vs actual needs and wants (191-210). Retrieved from: http://oro.open.ac.uk/16274/1/ESP_SIG2_Ch13_Nepal.pdf.

Thapa, Renu Kumari Lama. (2016). An action research on classroom teaching in English medium. Asian Journal of Humanities and Social Sciences (AJHSS), 4(1), pp. 97-106. Retrieved from:https://ajhss.org/pdfs.

Yasui, Miwa; Dorham, Carole LaRue; and Dishion, Thomas. (2004). Ethnic identity and psychological adjustment: A validity analysis for European and African American adolescents. Journal of Adolescent Research, 19, pp. 807-825. Retrieved from: https://journals.sagepub.com/doi/10.1177/ 0743558403260098.

Yin, Robert K. (1981). The case study crisis: Some answers. Administrative Science Quarterly, 26, pp. 58-65. https://doi.org/10.2307/2392599. 